\title{
The King is Naked - a very subjective look at child and adolescent psychiatry
}

\section{Agnieszka Wlazło}

${ }^{1}$ Dr. Emil Cyran Memorial Regional Neuropsychiatric Hospital, Lubliniec, Poland

\begin{abstract}
For quite some time now an increasing number of voices can be heard in the public space regarding the decline of child and adolescent psychiatry: shortage of specialists, shortage of hospital wards and permanently insufficient financial support of this branch of medicine. However, in all the media hum about this problem and in the debates about how to solve it. are we not losing sight of its essence?
\end{abstract}

Keywords: adolescent $\cdot$ psychiatry $\cdot$ child $\cdot$ shortage

\section{Citation}

Wlazło A. The King is Naked - a very subjective look at child and adolescent psychiatry. Eur J Transl Clin Med. 2021;4(2):7-9. DOI: 10.31373/ejtcm/144209

For quite some time now an increasing number of voices can be heard in the public discourse regarding the decline of child and adolescent psychiatry: shortage of specialists, shortage of hospital wards and permanently insufficient financial support of this branch of medicine [1-2]. Certainly such news are highly frustrating, particularly in the context of psychiatric hospital bedspace shortages or long wait times for consultations with child and adolescent psychiatrist. However, despite all the media hum surrounding the claim "there are not enough child and adolescent psychiatrists" and the debates about how to improve this situation, are we not losing sight of the essence of this problem?

My professional experience includes both adult psychiatry (that was my first specialty) and child/adolescent psychi- atry. In addition I am a trained psychologist and psychotherapist. I worked in various clinical environments ranging from outpatient psychiatry clinics, to open wards and acute psychiatric wards. I cooperated with psychology/pedagogy clinics, schools and courts. Over a year ago I returned to work at an acute psychiatric ward. Children with psychotic disorders or depressive episodes were always a small subset of my patient group. Indeed an increasing number of children and adolescents sought psychiatric help with diagnosing pervasive developmental disorders. However, the majority of the patients who sought help at my workplaces were children and teenagers with disharmonically developing personality or behavioral problems secondary to difficulties with regulating their emotions [3]. 
In the context of my clinical experience, I have several doubts. Are we certain that the main problem is the shortage of psychiatric health centers for children and adolescents? Is it necessary to build more child and adolescent acute psychiatric wards and outpatient clinics? Before we start trying to solve the problem, perhaps it is worth assessing what is the cause of it? Perhaps it is worth taking a look at the abnormal functioning of children and adolescents through the lens of causes, not effects?

Contrary to the mass-media headlines, majority of the teenagers who are admitted to the ward I work at are not patients with depression or psychosis. Instead, these patients are presenting deficits particularly in tolerating frustration and postponing satisfaction, which arose in the course of brain development, parenting and socialization. They don't need pharmacotherapy or even individual psychotherapy, but instead they need consistent correction of parenting and socio-therapeutic interventions, the fundamentals of pedagogical and psychological counseling [4].

The inability to cope with situations perceived as difficult and problems related to the teenager's attempts to define his or her own identity seem to more frequently result not in the weltschmerz of youth or in "feeling down" that is discussed with a fellow teenager and/or "treated" via listening to loud music, but instead in a suicide attempt. In addition, an increasing number of suicide attempts by teenagers seem to be instrumental or manipulative, e.g. „you took my cell phone (or other privilege), so I will kill myself." Also I observe an increasing ineffectiveness and powerlessness among the parents, teachers and even the staff of therapeutic centers, decreasing resilience of adults against manipulative statements and increasing shifting of responsibility for the child among parents, teachers, psychologists and psychiatrists. The final link of this chain of responsibility is always the acute psychiatric ward.

Someone might accuse me of trivializing a complex problem. No. I am not trivializing it. In my professional opinion the problems of children and adolescents should be treated seriously. However the focus, the center of gravity should not be on psychiatry because that leads us to medicalize problems for which help should be provided by supporting the family system, via interventions that support parents' competence. Such interventions are within the scope of practice of pedagogical and psychological counseling centers. In case of deeper problems in the family there should be easy access not to individual psychotherapy with the child, but to family therapy [5-6]. Instead, parents succumb to the illusion, amplified by the mass-media, that in case of problems with their child they should visit a psychiatrist who will solve these problems (or would solve them, only if there were more doctors with that specialty). It seems that children are no longer taught to solve problems, no longer taught to handle the consequences of their own behavior. Instead, teenagers exchange on social media and online forums tips about which medication is best for depression and arrange to see each other at "the psych ward." Isn't this sad? Doesn't this expose the inadequacy of our interventions?

We should not forget that once a child consults with a psychiatrist, the design of the healthcare system managed by the National Health Fund (NFZ) to some extent forces that psychiatrist to make a particular diagnosis. We doctors are well-aware of this situation and take it into consideration. However, once a child has medical documentation with a diagnosis whose ICD code begins with the letter "F," then its parents, teachers, etc. approach him or her as someone who should be treated, instead of raised or taught. Mass-media support the society's expectations by broadcasting images not of children whom nobody taught how to delay satisfaction, how to tolerate frustration or how to bear the consequences of own behavior, not showing images of teenagers with interpersonal problems or difficulties with building their own identities in an increasingly changing world. Instead, we are bombarded with media images of young patients who need psychiatric care.

Majority of children and adolescents with whom I had and continue to have professional contact with should have never entered the psychiatric healthcare system. On the contrary, we should make more effort so that they do not enter it at all. Psychiatry is a branch of medicine, therefore without any doubt its role is to help with differential diagnosis of mental problems. However, it is not the role of psychiatry to teach delayed gratification or coping with frustration, help develop a sense of causation and responsibility, etc. If we do not address the causes of children's and adolescents' problems with functioning, then in several years we will have to confront an increasingly powerless members of our society who will easily name their diagnosis (or diagnoses) and all the medications they were taking so far, but who will not be able to handle the typical difficulties of daily life.

\section{References}

1. Benton TD, Boyd RC, Njoroge WFM. Addressing the Global Crisis of Child and Adolescent Mental Health. JAMA Pediatr [Internet]. 2021 Aug 9; Available from: https://jamanetwork.com/journals/jamapediatrics/fullarticle/2782801

2. Stelmaszczyk D. Kryzys psychiatrii i psychologii dziecięcej: ponad 600 tysięcy młodych ludzi potrzebuje pomocy [in Polish] [Internet]. Polska Agencja Prasowa. 2020. Available from: https://www.pap.pl/aktualnosci/news\%2C763908\%2Ckryzys-psychiatrii-i-psychologii-dzieciecej-ponad-600-tysiecy-mlodych-ludzi 
3. Mahon NE, Yarcheski A, Yarcheski TJ, Hanks MM. Relations of Low Frustration Tolerance Beliefs with Stress, Depression, and Anxiety in Young Adolescents. Psychol Rep [Internet]. 2007 Feb 1;100(1):98-100. Available from: http://journals. sagepub.com/doi/10.2466/pr0.100.1.98-100

4. Lisiecka-Biełanowicz M, Biechowska D, Orłowska E, Molenda B. The prevalence of depression in children and adolescents under 18 years of age treated for mental disorders in Poland between 2005 and 2016. Arch Med Sci [Internet]. 2020 Apr 18; Available from: https://www.archivesofmedicalscience.com/The-prevalence-of-depression-in-childrenand-adolescents-under-18-years-of-age-treated,112197,0,2.html

5. Jiménez L, Hidalgo V, Baena S, León A, Lorence B. Effectiveness of Structural-Strategic Family Therapy in the Treatment of Adolescents with Mental Health Problems and Their Families. Int J Environ Res Public Health [Internet]. 2019 Apr 8;16(7):1255. Available from: https://www.mdpi.com/1660-4601/16/7/1255

6. van der Pol TM, Hoeve M, Noom MJ, Stams GJJM, Doreleijers TAH, van Domburgh L, et al. Research Review: The effectiveness of multidimensional family therapy in treating adolescents with multiple behavior problems - a meta-analysis. J Child Psychol Psychiatry [Internet]. 2017 May;58(5):532-45. Available from: https://onlinelibrary.wiley.com/ doi/10.1111/icpp.12685 